\title{
The End of Welfare As We Know It
}

\author{
What Happens When the Judge is in Charge
}

\section{Victoria Malkin}

Wenner Gren Foundation for Anthropological Research, USA

\section{Introduction}

A quiet revolution has been taking place within the US criminal court system. Independent of any congressional legislation, judicial reformers are advocating, and slowly implementing, a new court model broadly described as 'problem-solving courts'. ${ }^{1}$ In policy terms, problem-solving courts aim to 'use the authority of the court to maintain the social health of the community' (Butts, 2001: 121), and this is achieved by 'broaden[ing] the focus of legal proceedings, from simply adjudicating past facts and legal issues, to changing the future behavior of litigants and ensuring the future well being of communities' (Berman and Feinblatt, 2001: 126). In theoretical terms, this goal explicitly redefines the criminal courtroom and its outcomes as more than a judicial procedure for determining guilt, innocence, and an appropriate sentence: this agenda now reconceptualizes the criminal court into an institution whose processes and outcomes affect other social spheres. While this goal is not unusual within the ideals of constitutional law, nor within academic debates emanating from the law and society movement or critical legal studies (see Silbey and Sarat, 1987), the explicit statement of these policy goals within a criminal court setting entails an unusual expansion of state power as I will show below, albeit now clothed in the language of accountability and the public good.

Legal anthropology originated with the study of law as a system of norms and regulation across societies (see Nader, 1969), where order was maintained through mechanisms of formal social control as well as through ideological and cultural channels (Merry, 1992: 330). US ethnographies documented how the law is constituted through practice as opposed to existing as a set of fixed ordinances imposing social control from above (see, for example, Ewick and Silbey, 1998; Greenhouse et al., 1994; Merry, 1990). These studies rejected the idea of the law as epiphenomenal to social life, and showed how competing visions of legality engender social relations and social practice (Ewick and Silbey, 1998: 34-9). By necessity, US ethnographies primarily focus on a state-centered legal model, looking at 
the divergence between law's official version and its incorporation into local spaces where its meanings and consequences are reinterpreted according to different legal ideologies on the ground. Elsewhere, however, anthropologists in colonial and postcolonial states documented multiple legal ideologies in a local space, observing their interactions and showing how they reflect different temporal, geographical and historical moments (see Merry, 1991; Wilson, 2000). The current focus on legal ideologies elsewhere, with a particular emphasis on the global spread of a human rights legal model and debates over legal pluralism (see Merry, 1992; Messer, 1993), appears to render many of the previous debates over law and society in the USA somewhat out of fashion as debates move on, leaving the role of law and the criminal justice system at home for the criminologists, sociologists and political scientists (for some recent exceptions see Conley and O'Barr, 1990; Ewick and Silby, 1998).

Previously, US law and its changing practices was conceived of as a movement away from a conflict model of law towards a harmony model, where peace takes precedence over contention (Nader, 1997: 713). Concurrently, a shift from formal to informal models of justice was observed. These models coexisted and interacted, similarly to the examples of legal pluralism observed elsewhere (Merry, 1999; Vincent, 2002; Wilson, 2000). This shift gained momentum in the USA during the 1970s and 1980s when alternative mediation centers were set up to resolve disputes outside of the formal justice system and were found to champion consensus and harmony, even while their practices favored certain outcomes over others by steering complainants and defendants towards particular understandings of their disputes following local moral claims about what constitutes legitimate behavior, underpinned by ideals about gender and kinship, and individual versus communal rights (Merry, 1990; Nader, 1997). Furthermore, rather than representing a retraction of state power, informal models of justice were shown to extend hegemonic ideologies of normative behavior and justice (Abel, 1982; Merry and Harrington, 1988). Problem-solving courts continue to champion a harmony ideal: court actors are advised to act as a team to resolve cases and find a consensus in order to address a defendant's problem (see Berman and Feinblatt, 2001: 130-2; Davis, 2003; Nolan, 2001: 75-106). Pleading guilty allows the court to get on with its real business, that of engaging a defendant and mandating him or her to an appropriate treatment program to help address his or her issues (Winick, 2003). The defendant's appearance in court is the beginning of an overtly coercive process where the threat of incarceration is used to encourage him or her to take this opportunity to change. At the same time, justice remains within a formal arena where legal players and administrators stress the benefits of coercion and judicial leverage as a tool to encourage a defendant's compliance (see Winick, 2003). Therefore, while problem-solving courts can be interpreted as a continued shift towards a harmony model of law, this is not accompanied by a similar move towards informalism. ${ }^{2}$ 
In this article I continue in the ethnographic tradition of examining the legal process, and in particular, the criminal justice system 'at home'. This is a pertinent time to do so; not only has the prison population increased disproportionately (Garland, 2001: 208-9), but the pattern of arrests exacerbates existing structural inequalities along class and racial lines (McConville and Mirsky, 1995; Rhodes, 2001). As anthropology moves its eye to highlight the intricacies of power, produced by complexes of social relations and hierarchies ever more difficult to locate, dissect and resist, formal mechanisms for state social control and coercion have not evaporated. For some, the current expansion of the criminal justice system may appear clear cut in its cause - either following a structural and Marxist interpretation which interprets law and coercion as a response to the ongoing contradictions the emerge in late capitalism (see Chambliss and Zatz, 1993), or through a law and society model where coercion is understood to reinforce social distinction and norms within a society. Here, I discuss a more complex set of determinants underlying these new mechanisms for formal social control. Anthropology has remained somewhat silent on the increasing demand for a punitive justice system throughout US society and other parts of the industrialized world where governments and citizens have shifted to embrace more punitive models of justice, even when accompanied with the possibility of rehabilitation. These shifts follow the growing popularity of conservative political ideologies alongside notions of self-responsibility. But the embrace of this ideal across class and racial lines still remains unexplained. In this article, I examine the emergence of one model of justice - problem-solving courts - to demonstrate firstly, the arenas where these ideals flourish and, secondly, to show how courtroom interactions and relationships promote and celebrate them. Inside the court, discourses of personal responsibility and the individual self override debates over social justice and equity, and permit state coercion and control to continue unchallenged. I examine some of the implications of these changes both as they apply to the criminal justice system and its role in larger structures of power and control, but more importantly, I will use the example of the problem-solving court to continue some of the debates in the 'law as culture' argument, showing how the practices within the courtroom are part of a process that aims to enable actors to participate in the new neoliberal state.

\section{Legal reforms and govermentality}

Court reformers belong to an elite movement driven by judges and other legal actors (Nolan, 2001) who propose that the court should be used to solve social problems. Proponents describe the current system as a revolving door, unable to resolve defendants' underlying problems (Berman, 2000; Berman and Feinblatt, 2001; Rottman, 1996). In response, they 
envision problem-solving courts as a way to direct defendants into different social programs and supervise their progress. Defendants attend their programs as their legal cases proceed through the court system. Whereas previously probation, corrections, and parole have been responsible for directing and monitoring defendants in different rehabilitative programs (when available) after the determination of a sentence, in this new model judges have been actively incorporated and involved in the process as they mandate defendants to social services, in many cases prior to a guilty determination or plea (Lane, 2003). These reforms have taken off at a national level. The US National Institute of Justice fund and celebrate their success and small, specialized courts, for example mental health courts, drug courts, domestic violence courts and community courts, have opened throughout the country (see Bureau of Justice Assistance, 1998, 2000; Department of Justice, 1999). The courts thus act as a proxy gateway into social service programs for a large group of the population, and due to policing practices, primarily residents of lower income communities.

These innovations and reforms are received across the political spectrum as favorable. For the right, the judge's immediate intervention and sanctions alongside the judicial leverage over many who may just have minor violations allows it the rhetoric to remain 'tough on crime'. For the left, the reforms are a way to slip a rehabilitative agenda into an increasingly punitive criminal justice model (c.f. Garland, 2001; Kurki, 2000) and escape mandatory sentences for crimes such as drug possession. The rehabilitative ideal provided by treatment offers progressives an 'alternative to incarceration' (ATI). Drug courts, for example, were recently supported in a California referendum as an efficient, cost-effective and compassionate solution to the intolerable increase of non-violent offenders in prison exacerbated by a 'three strikes and you are out' law (Nieves, 2000).

Judicial reformers label the current system as 'broken', suggesting it could lead to (moral) chaos as corridors of untreated individuals are released back into their neighbourhoods, committing new and worse crimes. As a result of increased arrests, policy papers, popular articles, and activists argue that the current court system renders judges impotent in the face of an overburdened criminal justice system:

We get a lot of repeat business. We're recycling the same people through the system and things get worse. We know from experience, a drug possession today or an assault today could be something worse tomorrow.... What's going on in reality today - the plea bargains, the mill count, McJustice. . . For the most part, in overwhelming numbers, the traditional judge is ... pleading cases at arraignment. (Honorable Judge Judith Kaye, Chief Judge, New York State of Appeals; Berman, 2000: 80, 82)

The advocates of problem-solving courts also propose reform in response to what they see as a public disillusioned by the court system, who now lack faith in the court's ability to act for the public good (Berman and Feinblatt, 2001; Clear and Karp, 1999; Rottman, 1996). But the discourses they 
employ to advocate and legitimize court reform do so while simultaneously avoiding any larger discussion over race and poverty, obscuring it into a conversation about consumer dissatisfaction and consumer rights:

Although courts ... have become increasingly modernized ... they still fail to meet the needs of the justice system's primary consumers; the neighborhoods that experience crime and consequences everyday. (Feinblatt and Berman, 2001: 1)

In policy terms, these reforms are defended within a mantle of pragmatism (keeping criminals off the street in programs thus reducing crime), utilitarianism (the provision of services to a population in need who lack the appropriate services in their neighborhoods), and efficiency (it is cheaper to provide inpatient treatment than prison beds). It is also argued that the changes contribute to a new, accountable form of government. The ongoing professionalization inherent in these ideas is not that far removed from the language of the community economic development movement (Stoutland, 1999), and the problem-solving courts' promotional materials highlight how these innovations can appeal to local business and non-profit groups who may contribute to programs on the basis of the courts' contribution to local communities (Feinblatt and Berman, 2001: 5).This semiprivatization of the courts follows reforms taking place within many government agencies where decentralization and privatization of government responsibilities into a private sector is a growing practice.

These changes illustrate a general trend in policy making, where the technocratic language of efficiency and reforms permit reorganization while masking the underlying political and moral forces (see Goode and Maskovsky, 2001; Feeley and Simon, 1992; Shore and Wright, 1997). Judicial reformers argue that problem-solving courts permit the judicial system to address the public distrust of the courts, the crisis of confidence over the judicial process, and satisfy the 'consumers' of justice, even though no clear evidence is presented as to the causes of this 'public discontent' and as to whether distrust is more the result of dissatisfaction over distributive justice in the courtroom than a cry for new social services. Furthermore, in reality, the courts are confronted with a set of administrative and structural limitations, many of which lie outside of their control, such as increased arrests, overloaded courtrooms, inappropriate policing, budget cuts inside the criminal justice system and throughout the social service sector, and inefficient inter-agency co-ordination. Notwithstanding the very real needs experienced by numerous defendants caught up in the criminal justice system, ${ }^{3}$ the current round of reforms appears to be more of a judicial response to a crisis in legitimacy (see Fagan and Malkin, 2003).

As a response to the changes listed above, problem-solving courts have also adopted the practice of 'therapeutic judging' inside the courtroom (see Berman and Feinblatt, 2001; Winnik, 2003), a practice which encourages the judge to mandate social services, observing from his perch while 
also maintaining a 'therapeutic role'. In this role, judges are now cautioned to be 'sensitive to the psychological mechanisms of transference and counter-transference, and how they can affect communication in the judgeoffender interaction' (see Winick, 2003: 1069). The court is not only perceived as a coercive force useful to get defendants into treatment, but judges are now told to think of their role as a "leading actor in a therapeutic drama' (p. 1060). They are advised that their status and position can be used to help/coerce a defendant into finishing a treatment program, attend counseling sessions, manage an addiction craving, and improve his or her self-esteem, among other things (p. 1067). The new 'activist' judge now works in tandem with social service providers, clinicians and other legal players to guide defendants through their mandated menu of therapeutic programs, selected to address and manage their designated problems. Clinic staff, councilors, treatment centers and defendants themselves report to the judge on their progress. Poor compliance enables the judge to demand a sanction, from essay writing to a spell in jail, while good compliance results in a reduction in required court appearances, congratulations, pizzaz, applause, handshakes, certificates of graduation (for drug court) and finally even a reduced disposition or acquittal (all of these procedures vary depending on the specific courts which are left to design and implement their own programs, sanctions and procedures).

'Community' is rhetorically invoked in the design and justification of these reforms (see Bazemore, 1998; Sampson, 2001). And loosely defined communities, which shift rhetorically and geographically - communities of victims, addicted, sufferers, defendants and neighborhoods - all stand to gain. These appeals to a vague community echo a package of policies being implemented throughout advanced industrial societies where the ideal of governing through direct state interventions is being abandoned. The older model generated policies designed to organize society through a concept of shared risk spread across society, following the liberal ideal of a social welfare package available for all citizens during periods of crisis or need. While this older liberal state concerned itself with minimizing risk through the distribution of goods, the neoliberal state manages risk through a network of experts whose job it is to analyze and predict where and how it will emerge (see O'Malley, 2000). Neoliberal government now devolves more programs and power into locally administrated and privately organized programs encouraging participation, volunteerism, community engagement and partnerships (Cruikshank, 1999; Hyatt, 2001; Pavlich, 2000; Rose, 1996). While centralized social programs recede, the government expands its control through concepts such as alcohol (Valverde, 1998), crime (Simon, 1997), and community (Rose, 1996), where each becomes a symbol to determine high-risk 'populations' in need of regulation. Risk is no longer shared across society, and governance is now linked to the creation of risk profiles and risk management while reforms target specific groups, vaguely defined as communities, assumed to represent some sort of shared norm and values. 
The focus on 'high-risk' populations in crime control is a driving force in policy. Contemporary policing practices are increasingly managed through the concepts of probability and risk (O'Malley and Palmer, 1996; Pavlich, 2000; Smandych, 1999). Strategies focus on certain groups and neighborhoods, identifying and labeling spaces and certain people as potential problems, or criminals-in-the-makings, and managing them before the event. 'Quality of Life' policing in New York was justified through the idea of 'broken windows', which argues that signs of social disorder are the precursors for crime (Bratton and Guliani, 1994; Erzen, 2001). During the height of Mayor Guliani's 'Quality of Life' campaign, individuals could be charged for crimes such as jumping turnstiles, cleaning car windows or walking through a public housing development without proof of residence (see Erzen, 2001; Bratton and Giuliani, 1994). Quality of Life policing, alongside other policies, led to police targeting specific localities, frequently focusing on poor and minority individuals (Flynn, 2000; Rashbaum, 2000). In this rationale, police isolate specific spaces for specific problems, often calculated through technological advances that can isolate crime clusters and designate high-risk spots. Meanwhile problem-solving courts complement this policing strategy as specific offenders are labeled as a high-risk category for crime, and treated accordingly. Mental health courts, drug courts and domestic violence courts offer these defendants the 'opportunity' to address their 'problems'.

Initial evaluations of drug courts, based on sets of criteria such as case load dispositions, compliance in treatment programs, and rates of re-arrest, indicate that these courts are achieving their goal in terms of requiring individuals to attend treatment programs and reducing recidivism rates among drug court defendants (Rempel et al., 2003). While no one would wish to advocate that the court system retains its status quo, sending a parade of defendants into the inhospitable and punitive prison system, the creation of a series of speciality courts devoted to specialized defendant populations and treatment models requires a careful analysis. Not only are these courts redefining traditional court roles and procedures, such as sacrificing an adversarial model to establish guilt or innocence in favor of a team work approach where lawyers and judges debate appropriate treatment plans for defendants, the problem-solving model has also redefined the idea of a legal case: an appearance in the courtroom is now redefined as an opportunity for intervention and change, not just as a process to establish guilt and innocence.

In the problem-solving model the court extends its power over defendants, coercing them into programs and monitoring these programs. It also, simultaneously, increases the court's reliance on private agencies (treatment centers, social service agencies, even external funders such as private foundations and/or businesses improvement districts). For reformers, these changes are innovations for the social and public good, argued to increase government accountability. In practice, however, the new range 
of interactions and relationships influencing the judicial process and its outcomes are now ever more complicated to follow and interpret. For example, defendants' treatment mandates respond not only to the severity of the crime, but also to the opinions of social workers, the availability of insurance for specific treatment, hospital beds for detoxifications, and the eligibility requirements of particular programs - which can be as particular as forcing defendants to cut their hair to enter into a full residence (causing issues with one Rastafarian defendant I observed). The devolution of power into such a complex web means it becomes harder not only to trace how the final outcomes are determined, but also, protesting these changes becomes almost impossible from the perspective of the average citizen (see Cruikshank, 1999: 9-18).

Problem-solving courts fit into the larger systemic changes taking place in the USA. Courts replace older models of social welfare and recategorize individuals with specific problems, previously thought to derive from social problems and whose resolution was part of the social contract, into a high-risk category to be managed. These reforms highlight the end of the previous social contract between state and citizen. The state and social responsibility is now replaced with empowerment talk (for individuals and community), self-sufficiency, family values, and individual responsibility and participation (Rose, 1996). Such ideals form the basis for neoliberal versions of social good with real consequences for policy and individuals. For example, in problem-solving courts, the neoliberal state aims to use coercion to transform defendants into productive citizens if they take this 'opportunity to change' and accept responsibility for themselves. These changes are one way in which the state restructures its power, and attempts to manage the inherent contradictions of an economic model that exacerbates poverty and inequality. Nevertheless, the coercion within the court does not leave the defendant without any role in this system. Indeed, this coercion operates through an appeal to volunteerism (allowing the defendant a chance to help him or herself), and defendants respond by appealing to the same celebrated discourses. They insert themselves into the new relationships within the courtroom, in many cases successfully appropriating these new spaces and technologies of self for their own end, leaving their own imprints on how the court develops. And, as I will now show, the strength of this new legal model is not its overt appeal to power and coercion, it is the subtle way these appeals both allow for defendants to have both more, and yet less, agency within the complex machinations of the courtroom and treatment programs enveloping their daily lives. 


\section{Problem-solving courts, community solutions and the neoliberal subject}

My research took place in the courtroom and corridors of a new problemsolving court known as a 'Community Court', housed within the Red Hook Community Justice Center (RHCJC), in a lower income neighborhood in South Brooklyn. ${ }^{4}$ The impetus behind the court was the disorder and drugs that had ravaged Red Hook in the 1980s and 1990s, although somewhat abated by 2000 , when the court opened. Red Hook has one of the city's oldest and largest public housing developments, with a high concentration of black and Latino residents. The community court is an ambitious problem-solving court, arraigning defendants from three surrounding police precincts and aspiring to send them into appropriate programs and/or also assign them to community service projects. Not only does this court follow the problem-solving model dedicated to resolve the underlying problems of defendants, but the RHCJC also focuses on the neighborhood ('community') and aspires to adjudicate cases in a community context - noting arrests originating from particular hot spots such as street corners where drug selling is common, or targeting alleys where residents may have complained about prostitution. The legal players and the court have an expanded role as staff are asked to take the community into account as they resolve problems, design sentences and attend community meetings (Malkin, 2003). All cases heard at the court are low level charges: summons, misdemeanors and Felony $\mathrm{D}$ and $\mathrm{E}$ cases. As a result, the caseload is primarily minor assault (including domestic violence cases), quality of life cases, drug possession (from crack cocaine to Xanax), marijuana and criminal trespass (a category almost exclusively applied to individuals in public housing estates and used as police make sweeps throughout the buildings). ${ }^{5}$

The application of a problem-solving court model to low-level cases attests to the popularity of these court reforms. Many of the defendants might have been eligible for 'time served' on their charge if they had been arraigned at a centralized court system, while at Red Hook they are now screened and shunted into programs. When the RHCJC opened, it was heralded as a 'one stop social service center': defendants arraigned in the court could be sent to a variety of programs available on-site - job training, GED, counseling, anger management, marijuana groups, treatment readiness programs and a health education group for prostitutes (later adding one for men arrested while soliciting). Repeat offenders and those with long criminal records (rap sheets) can be mandated to longer-term outpatient or inpatient programs. Phoenix House, a national total abstinence drug treatment provider, has staff on site to immediately place defendants into their long-term inpatient treatment programs. The court began a weekly meeting for the judge, defense, prosecution, and social workers, who would together discuss the progress and failures of defendants 
mandated to long-term treatment plans and decide a course of action for those who seemed to be constantly failing, absconding, or still testing positive for drugs. Over time, the court sentences became more directed towards therapeutic treatment programs, which became more and more the norm (see Fagan and Malkin, 2003).

The court has adopted therapeutic language, where 'relapse is part of recovery' and hence non-compliance in treatment programs becomes a way to increase a court mandate, monitor a defendant more closely and at times require even more from him or her by increasing their mandate. A lowlevel case should not merit a long treatment program, but endless relapse and no-shows can make this an ipso facto reality as the defendant remains subject to the court's mandate. Both the judge and prosecution have discussed recidivism as a way to gain leverage over a defendant and thus to really 'work with a defendant'. Thus, recidivism - once a sign of failure on the part of the criminal justice system - at Red Hook and in other problemsolving courts now becomes a chance to 're-engage' a defendant. Criminals - that is, those who seem to have motivations not generated from craven addiction - stump the court. As the defense noted, those defendants with 'nothing to treat' (that is, nothing therapeutic), have their cases adjourned and heard in the downtown court, where, if they face a harsh judge, they could be sent straight to jail, losing the chance to benefit from the therapeutic approach. The judge and court remain invested in the therapeutic approach. Many a defendant is told that while it will be difficult, the most important thing they have to manage is their addiction - and once this is managed, other obstacles can be dealt with. ${ }^{6}$

The problem-solving court model is more than a pragmatic response to an inefficient or failing system. The democratic state needs to ensure it has citizens whose behavior and practices coincide with its goals. In a neoliberal model, this requires self-governing individuals who remain active, empowered and participatory as the state recedes, in contrast with the liberal subject who was constructed in an environment of shared risk and who benefited from social programs intervening across the population. Such a liberal subject is now redefined as dependent and deviant, as exemplified in the debates over 'welfare mothers' (Cruikshank, 1999). These new courts respond to a dilemma faced by the neoliberal state: how to manage those populations that appear to be unable to manage themselves, or, in another sense, which refuse to align themselves with the needs of the state. In the current environment, the problem-solving court can be seen as a mechanism to deliver services to a population who refuse to 'get with the program', whatever name this may now take.

New managerial policies applied across welfare offices and social service agencies have not eradicated individuals in need. The continued need for social welfare programs, albeit now administered (coerced) through a court, show how despite the rhetoric, the neoliberal state still needs to directly intervene and engage its populations. The court reforms 
highlight the contingent nature of the neoliberal subject: self-reliant but expected to act within social structures that continue to maintain social exclusion, racial inequality and poverty. In problem-solving courts, such individuals are reconceived as directly responsible for their predicament through their mistaken choices. The role of 'society' in their fate is stripped away. Debates over the role of nurture or the 'truly disadvantaged' disappear into rhetoric of failed individual decision-making. An arraignment at Red Hook is an 'opportunity', in the words of the judge - the easy work is going to prison, the real work is going through the program.

But these new policies operate within a social context. Technocratic policies and administrative rulings turn individuals into clients, consumers and communities while issues of class and race are vanished into a language of consumer rights. Nevertheless, reality bursts into the social space as the 'community' being served and the new risk management being applied to improve public safety often target and operate in low-income, majority black and Hispanic neighborhoods. In Red Hook, the new local decentralized court and policing operations take place in a neighborhood where decentralization has often worked to create 'communities' which are governed or disciplined. The lessons from the War on Poverty in the 1970s in New York can be taken as a prior example. This government agenda targeted extra resources and services to the inner city, primarily African-American neighbourhoods, advocating local government and community control. Such directives were also in response to the civil rights movement and black radical activism (Gregory, 1998). Mayor Lindsay in New York City set up a new system of local government which, from 1965 to 1970, instituted initiatives from 'neighborhood city halls' to urban task forces, to expanded community role boards, and finally in 1970, to formalized neighborhood action plans (NAP). All these programs used the language of 'problem-solving' within a community framework, and operated by linking community residents and groups to city agencies, channeling grievances, and resolving problems. The early neighborhood halls in storefronts offered multiple forms of help. In the words of Lindsay, describing one of these storefronts in a Queens neighborhood:

[M] ore than 2,300 problems were brought to the city's attention. ... [T] he complaints ran the gamut from housing to streets and sewer conditions, from abandoned cars to welfare problems and requests for traffic lights - all services the city tries to provide for its people. ... [T] he hall was staffed by three professionals supplemented by volunteers who ... could channel complaints and problems directly into the machinery of the city administration. ... [T] he results were impressive. ... [M] ore than 8,000 in the first nine months [citywide]. More important however was the fact that local residents realized their neighborhood city hall was an effective mechanism for getting grievances resolved. (Katznelson, 1981: 137) 
Grievances have not changed in 20 years of different experiments, as complaints in Red Hook echo these same problems. Government initiatives channeled resources, services and government into inner-city neighborhoods. They were also instrumental for neutralizing some of the more radical black politics that were emergent in these communities as residents were energized to discuss local issue-based causes, and conflicts became defined in local terms and reframed into a community orientation. Decentralization was one way to resolve urban crises as people became endlessly engaged in participation and meetings (Gregory, 1998: 85-106; Katznelson, 1981: 176-89; O’Connor, 1999). ${ }^{7}$ Creating local communities can erase other commonalities of experiences based on race and class for example. Furthermore, many of the leading radical actors were incorporated into the more predictable political process, leading then to complex cycles of co-optation, corruption and power struggles over resources.

While the War on Poverty distributed goods from a centralized state through local political channels, the new semi-privatized court looks for private and public partners to form a team focused on problem-solving in local spaces. The state therefore maintains the channel to distribute goods and exercise power, while it provides less and less of the actual goods and resources. The community, as opposed to the 'social', is governed and envisioned as the source of change. Gone are debates over social programs for the citizen; now we have community programs for the local (see Hyatt, 1999). Community replaces society in an ideological map of the nation: we are now more a nation of communities than of citizens and society. As Rose has argued, the appeal to community is a new vector in government. It is not only used as an explanatory variable for life chances, but as a way to govern in itself.

It seems as if we are seeing the emergence of a range of rationalities and techniques that seek to govern without governing society, to govern through regulated choices made by discrete autonomous actors in the context of their particular commitments to families and communities. (Rose, 1996: 327)

By localizing each problem into small jurisdictions with no central hierarchy, and dividing neighborhoods into local communities who no longer align in larger political blocks, the decentralization of the court system may improve the court's performance, but it does not have a neutral effect on community organization and political participation. Not only does the court govern through community, it is 'governing through crime' (Simon, 1997). Governing through crime previously led to increased incarceration, alongside reinvigorating debates over family, community and social norms. It also engendered policies such as the War on Drugs, targeting large amounts of resources into neighborhoods and claiming interventions in the name of public safety as opposed to poverty. Currently, governing through crime continues the transformation of the liberal discussion about 
poverty and exclusion into a neoliberal discussion over space, public safety, and crime.

Decentralized local courts serving local communities transform national social problems into local community issues. Meanwhile, the overt coercion of individuals into treatment programs and therapeutic groups validates the idea of a new 'therapeutic state' (Nolan, 2001), expanding the power of the judge over those who appear in front of him or her. The court mandates young, old, working, under-employed and unemployed to different forms of groups and 'therapeutic justice'. The advent of selfesteem discourses, personal empowerment programs, self-help groups and therapy flourishes throughout popular culture, from Hollywood to the White House. The overt coercion, and the flourishing 'technologies of self' applied through the courts, managed through judges, and imposed on individuals recycled through the criminal justice system, is understandable within the currents of both the political and popular culture. What is less clear, is why they are accepted by many individuals, for in my observations, the overwhelming response of many defendants towards the new court was positive. The court engenders new forms of power as it becomes both more and less coercive. More, as the court sends more individuals into programs and monitors defendants for longer periods of time, and less, as its practices permit the defendants to respond and attempt to exercise their own understanding and agency throughout the process. In this new model, the legal process is transformed from a legal ruling into a referendum over the relationships the defendants construct and maintain in the courtroom, as will be described below. However, to assume that the positive reception of the court by defendants means that these technologies have been successful at refashioning new 'democratic' subjects reduces defendants to empty vessels waiting to be reformed - in itself similar to the therapeutic model which assumes that the subject requires self-transformation. It thus denies both the defendants' understanding of their role in the court and within these power relationships, and denies their agency in these processes and subsequent determination, to which I now turn.

\section{Self-transformation, motivation and a new relationship}

The use of the court to mandate defendants into social programs presents everyone involved with varied options. Recommendations around a defendant's clinical needs are provided by an on-site clinic, and then negotiated by the other legal players involved in the case. The judge, keeping in mind the severity of the case and the defendant's criminal record, sets a mandate - at times consulting with other court actors, or even directly consulting with the defendant and trying to assess his or her 'motivation' for change. For those with extended prior contact with the law, 
recommended treatment programs can range from 30 to 90 days for drugs, alcohol, anger management and other issues. By the end of my fieldwork, one defendant with multiple reappearances in court was mandated to a two-year inpatient total abstinence drug treatment program. The final mandate is a complex balance of opinions and needs - from the court's need to resolve and dispose of cases, to the social worker's recommendations, to the judge's belief in the defendant's 'readiness for treatment'. But on top of these considerations, the mandate is further determined by a defendant's insurance and a treatment program's availability, among other issues. The court primarily aspires (conspires) to resolve cases by mandating different social programs, and/or community service. ${ }^{8}$ Defendants also know this. Alfonso Ramos was a young Hispanic man, arrested after the police observed him buying crack cocaine. He was just shy of completing a five-year probation for selling drugs and knew his record preceded him into the courtroom. He first heard about his options while waiting in the holding cells:

Victoria: In the cell when you were waiting, did anyone know about the court?

Alfonso: There were some people who already were in there before who said that 'everybody that comes here goes home, nobody goes to jail.' .... So I was like, maybe I am going home, if they are saying that, it is because everyone goes home from this jail ... so when I saw my lawyer, she gave me options that if I took a drug treatment program I would be able to go home, if I just took a program.

Alfonso pleaded guilty and agreed to a 90-day outpatient program, paid for by Medicaid. Later he was rearrested driving on a suspended license. He then informed his lawyer he did not use drugs but was buying drugs for a friend, which had not seemed to be a risk as he knew the sellers on his street. He had tested clean throughout his program and when I met Alfonso he had just managed to renegotiate his sentence and close his case by agreeing to do 10 days' community service (most of this cleaning the court itself):

Alfonso: Afterwards I got a little sick of it [treatment], cause I had to sit with people that use drugs, and they constantly talk about drugs and basically I got tired of it cause I am not a drug addict. So that was very frustrating for me, because in reality I didn't need drug treatment, I just wanted to get out of jail and I got tired, I got tired of going three times a week to some place where I don't need to go, it was annoying. ... So being that I came back in the system, I then took the chance, the opportunity to tell the judge.

Victoria: Did you tell your lawyer?

Alfonso: I told my lawyer that I really didn't need drug treatment, that I didn't want to go anymore, cause I was sick of it, cause I didn't need it to begin with ... the lawyer just basically told the judge that I lied.

Victoria: Did you have to go see the clinic?

Alfonso: Well I had to go see the clinic one more time.

Victoria: And what did they say? 
Alfonso: Um, they put me in front of the judge and I had to tell the judge that I don't need a drug treatment program for the first time of my arrest, that if he could give me other options ...

The court needs to resolve cases. Its performance is monitored by the Office of Court Administration (OCA) using data on case dispositions. A guilty plea accompanied by a treatment mandate is a common denominator that maintains success: the defense keeps its clients out of jail, the prosecution finds a way to 'punish' with 'tough love', and the ideological premise to resolve underlying problems is legitimized as individuals are sent to different treatment programs. This solution also leads to the evolution of an 'ideal type' for a defendant. 'Risk Management' is in play as the court tries to anticipate which of the defendants will most likely respond to treatment, avoiding the accumulation of incompletes and failures in the data. Those defendants with long criminal records have least room to maneuver legally, even if their current case is as minimal as jumping a turnstile. Defendants are also most malleable when they either have their own health insurance to cover the treatment, or they are eligible for Medicaid. William McNight was one such case. An African-American man in his 50s, he was arrested on a drug possession charge while leaving the public housing development in Red Hook where police were conducting a sweep. He had a previous criminal record, although no contact with the law for some five years. William told the lawyer and judge he had a drug problem. He also had HIV. He had heard about the Red Hook Court through friends: 'They give you a chance, or some other alternative ... jail is not the issue there.' Even so, in the courtroom he maintained his innocence (in fact he had swallowed the crack when detained). He was surprised that his only option was a drug detox program or bail (i.e. sent to jail awaiting sentence):

I didn't understand that, being that there wasn't any evidence. . . . I felt that I was innocent until proven guilty. ... It seemed like the DA had duped something up and the judge was in agreement with it. .. . [in court] I was beginning to be sick from not having drugs ... and now the judge was talking about really sending me to jail. ... I said, 'your honor.' He saw that I wanted to speak, 'I don't understand this'.... I explained to him about no police contact [for five years] and [asked] what is going on here and ... he says, that he is looking at me and seeing my condition and situation different, and 'I am trying to get away from the drug charge', and he is looking at me as a person in trouble so he really wanted to hold me in long enough to get me some help. I didn't really see it that way at the time at all.

After negotiations, William agreed to an immediate five-day detox program. He then phoned his lawyer and asked for his proposed sentence to be changed from a 90-day outpatient program to a 90-day inpatient program, calculating that he would probably fail if he attended an outpatient program only. He pleaded guilty in return for this sentence, and the case was to be dismissed on successful completion of the program. William 
attended a program in a specialized clinic focusing on HIV-positive men and drug addiction:

William: My addiction didn't allow me to fight [the case]. At that point I didn't have the strength. ... I was staring [the judge] down like 'I know what you are doing.' He says, 'Would you like to say something?' I said, 'I know what's going on, you are railroading me here .... I know that you are offering me help and a detox and I am not crazy, I'll accept that ... but on the other hand, the reason you got me here is not really copasetic, the way you snatched me up and just stood me here.'

Victoria: Is this what people expect from the judge? Or they don't like it? Or they feel it's, you know, whatever the judge ...

William: They like to go to Red Hook Court. . . . Now I know why, because there is opportunity there. There is a chance. Everybody who is using doesn't want to be using ... but given the opportunity, given the chance, a moment's chance, they know that 'Oh man, if it could just work this time.'

William is an example of a 'success story'. On his 'graduation' in court he wore his best suit, cried, hugged his lawyer who had worked diligently to help him stay on course while he waited for a bed at the treatment center, and listened to people applaud. In fact, these displays motivate others to consider the possibilities offered by this new opportunity. Juan Ramirez, another defendant with a long rap sheet, was searched after leaving a friend's house in Gowanus housing. He was carrying a bag of heroin in his pocket. He accepted a 90-day outpatient program:

Victoria: Do you think the court will make a difference?

Juan: Yeah, it does make a difference, cause now my aim is, I am tired, really tired, I am tired of this. ... I am more open, I wasn't really open. I was holding a lot back. Now I am trying to get my life together and that is something that the court showed me... . To tell the truth, that is not something I got from the court, it is something I got from the judge . . . because I remember when I was in the courtroom this time, there was this lady ... she completed a program and everything ... and that is the first time I have ever seen anything like that, and the judge said you deserve a round of applause and everybody applauded. I never seen that in a courtroom. ... That was unique.

On the way to one of his court appearances he was rearrested stealing deodorant from a Rite Aide drug store. After working all day, he had not wanted to smell in front of the judge in court. He was mandated to two days' community service for this offense. Meanwhile, his attendance at the treatment program was patchy. The outpatient program diagnosed him as bipolar and felt they were inappropriate for his needs. As Juan's case became too messy for 'success' it was closed. The judge reduced the sentence to 10 days' community service. In spite of Juan's inability to carry on with treatment, he decided he wanted to continue, but outside of the watchful eye of the court: 
Juan: [The court] force it on you ... they actually think you cannot make no decision because you are making the wrong decisions if you end up in jail. If you end up in jail, the person is in jail because he made the wrong decision, so now it is time for us [the court] to make the decision for you.

Victoria: How do you feel about the idea that you can't make your own decisions?

Juan: I can make my own decisions. I could ... I get up every morning .... once they close the case, I do what I do. I gotta go to this program that [the clinic director] is sending me, the same thing that the court is sending me. I am doing it on my own ... I don't need no one telling me ... I know that if I show up late or I don't show up. I know that I will show up and if I can't, it's cause I have a good excuse. I have to go to work, and I have to work around that.

In reality, while the court started with high goals and long-term treatment plans, over time the clinic and court had to cope with defendants who were failing in the treatment programs. After some time in operation, the clinic director and others advocated closing defendants' cases whose duration in court was constantly extended due to their repeated failures (such as testing positive for drugs, not attending programs regularly or failing to appear in court). The court began to look for defendants most likely to succeed, and the clinic categorized other defendants as 'not ready for treatment', leaving the court to find them other mandates, ranging from community service to jail.

Defendants are painfully aware of the court's coercive powers, and those with repeated contact with other courts often calculate that their current charge would probably not have merited the same level of intervention in the central court system. They have learned to maneuver within the confines provided by this new model. They know their record precedes them, not their accomplishments. Indeed for these individuals whose lives have been peppered by encounters with the criminal justice system, they see themselves as functioning symbiotically within a system (see Malkin, 2003). The popularity of treatment programs and other sanctions is one more language they learn, as is their knowledge of the law and medical insurance. This language, and their attempt to manipulate it through the relationships they form with the court actors, permits them to feel they have had more of a role in determining the outcome of their court case than in the downtown system. In Red Hook, the court is frequently called on to make a determination between the fine line that separates 'motivation', 'relapse' and absolute 'failure', when deciding how many chances to give a defendant. While the court actors could decide in their weekly meeting to mandate a defendant to jail instead of letting him or her continue treatment, the judge was not unknown to reverse a social worker's recommendation to discontinue treatment or impose a sanction after a defendant pleaded directly to him, assuring him of his or her good intentions or otherwise. In this model, relationships matter. Not only in terms of how the court 
decides on an appropriate mandate, but also in terms of the defendant convincing the judge and others as to his or her 'real' or 'true' self and intent. Defendants use all the possible tools they have to direct these procedures. Daniel Santos was arrested during a sweep with heroin in his back pocket. He had spent time in prison upstate, and had open cases pending in other courts. He was sentenced to 90 days' outpatient treatment. Over time, he tired of the program, and problems with paperwork and payments began to threaten his position in it. The complexities of his situation were hard for me to follow:

Daniel: [The court] tried to get me another program, didn't work ... legal documents, I always get legal documents.

Victoria: So they never found you another program ... that was for the first case [he had been rearrested several times since his first court appearance]?

Daniel: The first, I got them concurrent . . they increased the time to 90 days outpatient. . . . I refused. . . . I didn't want it, so I made a problem that they didn't accept.

Victoria: What do you mean?

Daniel: I made a problem happen that they did not accept me ... my Medicaid. I ran my Medicaid. I maxed it ... so I offered them, give me 10 days community service and I'll walk away with it.

Victoria: So what happened?

Daniel: What you trying to understand? What you got to figure out? I am trying to explain to you and you keep asking the same question a hundred times. I came to the people in the court. I made an agreement with them - let me start off . . you see I know the system. I have been in prison all my life. I know about law and liability and all that. So I broke it down to them. I said the program isn't working for me. . . So I want to be supervised, watched over me. I will come every day of the week [to the court]. So my urines were coming up clean. [The court] saw me high out of my head, but they couldn't see no urines dirty [defendants have various ways to try and manipulate urine tests]. ... I told them 'you see that they are coming back clean. Why don't you just, for the 90 days why don't you give me 10 days community service?'

While many defendants adapt to the language of the court, for many, even those who do not manage to comply, their time in treatment also leaves a mark. For some, it provides them with a space within which they begin to contemplate their life outside of being in a system they have to manipulate, but in terms of a self they have to 'find'. Eduardo Jones, a black man in his 30 s, had been in jail upstate for robbery and other drug-related crimes. After leaving prison five years previously he had stopped using drugs. He had been arrested for criminal trespass during a sweep and, like the examples above, his rap sheet had convicted him in spite of his five years away from problems. In court he had been surprised to learn that he was being set bail (thinking that this arrest downtown would merit a time served). Aware that he was being convicted by his criminal record he 
pleaded guilty and accepted a mandate of 90 days' outpatient treatment (three times a week). I met him for lunch after he had completed his mandate:

Eduardo: Most people who go [to treatment], and don't want to do something that they're supposed to do, it's because they haven't met real people and talked to them. You see, once you have someone who can identify with your story, who can understand where you're coming from, that probably is better than an addict talking to another addict. Because they have something in common besides substance abuse ... And you have stories that they can share. So, you either gonna get your life together or you're gonna wind up dead. ... But to me $[\mathrm{X}]$ program cares about people. It's a very good program. You meet very important people in there. The difference between [X] program and $[\mathrm{Y}]$ program is that you have a different variety of people. You have people who are lawyers, doctors.

[Later, as he was discussing his mandate, he continued]

Eduardo: Listen to me, everybody needs therapy.

Victoria: You think?

Eduardo: Because once you get arrested, the time that you spend in prison, the little time that you spend there, whether it's seven hours or eight hours or ten hours, it takes a toll on your mind. Because that one minute, or that little eight hours that you are locked in that cell, you have time to get into yourself you see. And somewhere along the line you need help. Because if you didn't need help, you wouldn't have been in that situation you're in.

Eduardo contacted me two or three times after our meeting, he was losing his apartment and wanted help. He also wanted to find a new job. These real-life problems were not ones the court could really solve. It has one nonprofit program in its basement for resumé advice, and some housing advice. But Eduardo's practical needs remain unchanged and are left up to him. In this new model, the new subject is encouraged to believe he or she can triumph over social problems through individual autonomy and selfempowerment. Defendants may leave their program having found a resting place, or armed with new selves capable of making rational informed choices, but they are often still unequipped to manage social conditions, or escape policing practices that put them back into court.

Defendants perceive themselves as part of a larger system, where they are inserted into a symbiotic relationship with the police, suspicious that policies such as Operation Condor and Quality of Life encourage police to meet targets while knowing that they provided police with overtime pay. More then a few saw their arrests as fulfilling multiple needs. They recounted how they had been forewarned by police about the 'Red Hook Court' where, the police told them, they would most likely not go to jail, because that was not the court's purpose. Defendants also know they are judged by their criminal record. Yet the chance to negotiate in court and address the judge directly allows many to feel they are directly managing their situation; some even speak over their lawyers who try to quiet them as 
they plead directly to the judge. Many continue to feel that the 'judge is fair' and that the 'judge gave them a chance'. Defendants such as Daniel Santos (described above) frequently described their court case in terms of their relationship with the judge:

Victoria: You have sat in court a lot.

Daniel: Sometimes ... I had to wait for them to call me. I used to go down to the courtroom and just listen like you do. Just listen. The judge is reasonable, I really think he is reasonable.

Victoria: Do you think he understands what is going on?

Daniel: I think somewhere down the line he knows that. Or he has a family member, or something, who does drugs, or something, cause he is very reasonable. ... Thank God he smiled at me, while the DA wasn't trying to let me speak. He said let the guy speak ...

Victoria: And what did you say?

Daniel: I was talking to the lawyer and the judge. I told the judge, you know, I feel that I need help, you know, and uh the DA is trying to hang me here, and he was like, 'OK.' Boom. 'So what do you think would help you?' He is like that, he would rather see you try to do good for yourself. I told him, I'll go to rehab.

The Red Hook Court enables individuals to express themselves in the courtroom, actively promoting the idea that they can control their own fate. In Red Hook, the line between defendant and client is blurred when the court imagines itself as acting for the defendant's good. Such a blurring gives the defendant a role. For defendants, their agency is now part of the courtroom drama. They can try to turn the sentences in their favor, and their long exposure to judges and lawyers with the ongoing reappearances in the courtroom means that the defendants form relationships within the court and use these relationships to try and make things better for them. At the same time the court works within a discourse of self-responsibility and individual choice, starting in the courtroom, where the judge and lawyers constantly remind defendants they have a choice to make. This same message is echoed in counseling and treatment programs. From the initial court appearance to the subsequent mandates, defendants are reminded that the choices they make and the subsequent consequences are theirs and theirs alone: American individualism at its height is offered. Even Eduardo Jones, who protested his innocence and bemoaned he had no choice but to go to treatment given his record, weighed it up in the following way:

Eduardo: See, you can only offer things to people. It's got to be the individual that wants to do this. You have a lot of opportunity out here in America, but it's up to the individual to grasp it. You can't force a person. Now there's certain situations people are forced to do certain things, in certain situations. Then when you're not forced to do certain things, you don't do it cause you choose not to. Some people need that forcing for them to get their lives together.

Victoria: So you think that in a sense that idea of forcing people into treatment will work? 
Eduardo: Yes.

Victoria: They wouldn't slip up?

Eduardo: Do you know why? Do you know why I say, sometimes pressure can help people? Because there's a lot of sick people running around here. And they need help and they don't know how to grasp it or go to someone and ask for the help. There's some sick people out here.

\section{Untranslatable categories and stubborn subjects}

Problem-solving courts encourage those who are willing to work with them. Defendants adeptly learn these discourses. Some are better than others at taking what they need and moving on; others truly ascribe and benefit from a new therapeutic discourse. For some, discouragement and disillusion with the system was transformed into self-blame as individuals assimilated into a therapeutic mode. Others found a safe space in programs and groups that allowed them to look at their lives as they are, and provided a break from the daily struggle and hustle on the street. Some constantly failed, relapsed, and absconded. These individuals could be dispatched to community service if it was felt they had tried hard enough, or sent to jail if it was felt they hadn't.

The court may or may not be successful in its ability to align defendants with drug problems alongside its own needs and goals, but certain categories are more problematic and less easily aligned, such as those 'problems' less easy to diagnose and treat as a medical pathology, or those not so simply defined within a therapeutic discourse. One group clearly exemplified this - prostitutes. The court often announced its efforts to control prostitution, informing local residents how it had successfully managed to discourage this in certain hot spots through the imposition of more arduous mandates, provoking many prostitutes to move on to other bars in other neighborhoods, rather than risk having to participate in health groups and community service crews at the RHCJC and forfeit their daily wage.

The court was aware of the challenge these young women present, where the mantra of therapeutic redemption, and self-responsibility alongside choice, seemed rudely misplaced. Their mandates continue to construct a deviant subject, mostly focused on the drug addict forced into prostitution to support her habit regardless of the consequences. For example, health classes informed them about STDs and the dangers of not using condoms which, as one woman proclaimed, was the first thing any prostitute learns. At the same time, a large number of the prostitutes were actually Spanish-speaking immigrants, some as young as 15, who were working inside brothels. Even the leader of the health group noted that this was not what these woman needed. Prostitution was not the result of a drug issue, it emerged from vulnerability, lack of job opportunities and other 
issues. One Colombian woman summed up as she began to cry: 'Telling me how to put on a condom tells me that I will be a prostitute for my life.' She then asked why the court could not help them find jobs. She later phoned me seeking advice for her son and his college application. She had stopped working as a prostitute, and was trying to find work cleaning because she was too worried about being rearrested.

\section{Conclusion}

Community courts can be interpreted within different frameworks. From the perspective of power, governance and the creation of new subjects, the courts can be seen as part of larger systemic and cultural shifts, while following a longer history of decentralization/centralization, the courts can be placed within a social context of declining resources, community unrest over 'Quality of Life' policing which has caused tension in some lowerincome communities, and political power. In different frameworks the set of questions changes and we need to consider the courts' unintended impact alongside their intended impact. Structurally, the courts represent the shift of social welfare across the nation to the distribution of dwindling resources into local communities to encourage individual empowerment. The emergence of decentralized courts as a mechanism to manage unruly populations may be an efficient policy change, but it remains one more example of a policy change that masks a moral agenda. The courts oversee large numbers of individuals, the majority poor and people of color. While previously the 'war on drugs' has been waged through practices of overt policing and formal social control, now problem-solving courts arrive to add a new twist. Still part of the 'war on drugs', problem-solving courts bring services and intervention to the poor, but legitimized through a discourse of public safety as opposed to social welfare. At a police precinct meeting, the precinct captain informed the public that 90 percent of crime is drug related. Meanwhile the problem-solving approach redefines crime as a therapeutic (scientific) problem, where poverty is erased as a causal determinant. Policing and unfair arrests disappear as the discourse moves into a therapeutic mode. Increased policing and longer criminal records form the backbone as they enable the court to have more leverage and control over individuals, and the unsuccessful 'clients' can be sent back into the prison population. This separation of defendants into those who want to help themselves, and others, turns prison into a choice. Individual selves are what matter, and the system is there to engender these and provide them with a chance to change.

Defendants enter into these new power relations. In court they confront multiple levels of control: a complex of actors interact to discuss their 'problem' and 'resolve' their case (cases are no longer won and lost in the harmony model); better technology and information sharing erases 
the more traditional mechanisms defendants have used to fight their cases. Once in court, unable to protest innocence when the diagnosis is a problem, not a crime, defendants find new ways. Relationships within the courtroom are one way for defendants to build up some means to respond. Other defendants refuse treatment point blank, still others ask for jail when they know they will never finish a total abstinence program. Finally, many just curse the judge when he has had enough of constant relapses and he decides that 'relapse is no longer part of recovery' but a sign of stubbornness and lack of motivation, handing out jail as the final punishment and reminding defendants that they can return to ask for help when they are released.

Problem-solving courts embrace popular narratives prevalent within American culture that prioritize the idea of an individual self. Defendants also embrace these narratives, and use them to try and direct their progress through the legal system, thus both endorsing the shift to more active coercion and simultaneously attempting to manipulate their way through the system. Defendants have learned to work and benefit from the system through newer maneuvers that rely on the presentation of a self-motivated person. Furthermore, for many the focus on relationships within the courtroom provides them with a possibility of expression and voice, which constructs their agency in a system that relies more on personal relationships and subjective perceptions than on legal codes and adversarial approaches. The judicial discretion granted to the judge in a problemsolving court means that the defendants play a role in the development of this system. Governance is more than a series of policy changes described by new ordinances that represent the neoliberal state. These changes and their implementation are the result of how these practices are implemented on the ground and received by citizens. The Red Hook Community Justice Center shows the majority of defendants accepting these changes and its concurrent rearrangement of power, because they feel they can influence and manipulate it. They also understand its language, in some ways more than the legal scientific language presented in traditional court. The court subscribes to a set of categories with which to understand the problems of those it seeks to help. It has prioritized a therapeutic discourse and uses it to legitimize its expansion of power. In this discourse, change begins with the individual, and is rooted in a narrative of self-esteem, motivation, suffering and finally transformation, which is instrumental for change. This ideal of self-transformation enables the creation of communities of suffering and overcoming. From President Bush to Robert Downey Jr, a successful person is one who fights to overcome adversity (such as the disease of addiction). They can feature on Oprah and preach away obstacles: adversity can strike all - rich or poor and this creates the great equalizing discourse where poverty and inequality is just one more mirage that the self needs to stop blaming for its weakness. Indeed, appeals to change, new starts and transformation echo 
therapeutic language heard through popular culture today. Sherry Ortner (1991) once argued that race is a conversation about class in the United States. It seems that in the new neoliberal state, one could say that therapy and transformation is the same conversation, it is just the question of whether its application is voluntary or coercive. The rich check into rehabs, the poor into courts. The court has extended its power in new and different ways, incorporating shifts in popular culture and finding a shared language. Politics and power are played out through culture, and appropriated in ways in which the new subjects can be both coerced and liberated at once.

\section{Notes}

1 See special issues of Law and Policy 2001 vol. 23 (2), and Fordham Urban Law Journal 2003 vol. 30 (3) for examples and discussions about these new courts, as well as the website of the Center for Court Innovation - one of the major organizations responsible for promoting their implementation - www.court innovation.org

2 Coercion has always been part of the juvenile justice system, but this new model extends a paternal model across a cross-section of defendants most of whom, due to the way policing operates, are lower income, minority and male.

3 This is similar to a situation in the 1980s where lawmakers advocated for alternative dispute centers without addressing whether there was a real need for them, and when in reality many communities had their own mechanisms in place for informal dispute resolutions (Merry, 1982).

4 This research is part of a larger study and evaluation of the Red Hook Community Justice Center, conducted at the Center for Violence Research and Prevention, Columbia University, supported by Grant 2000-MU-AX-0006 from the National Institute of Justice. The research took place from October 2000 to December 2001. Ethnographic work included participant observation in the court, the surrounding neighborhoods, regular attendance at community meetings, interviews with defendants, court employees, other representatives of the criminal justice system both inside and outside of the court, and community residents. I attended operations meetings in the court, various sanctions and treatment groups (such as the marijuana and quality of life groups, job training, and treatment readiness programs) to be familiarized with the content and observe the defendants' responses. I regularly attended the Red Hook public housing tenant association meetings for Red Hook Houses, Red Hook Civic Association Meetings, meetings at the 76th police precinct, and other community meetings as they arose. I had frequent informal interviews with court employees, defendants, and neighborhood residents. I also tape recorded and transcribed formal interviews with 59 individuals and 13 community service crews in the court. I am grateful to the Center for Court Innovation for its generosity and cooperation in all aspects of the research.

5 The RHCJC differs from many other problem-solving courts; not only does it arraign a large number of defendants with different problems, but arraignments are nearly all summons and misdemeanor cases. This contrasts with drug courts where defendants are all classified with a similar problem (addiction), 
and whose cases are more often felony cases where the alternative sentence would be a long jail sentence.

6 In a recent drug court evaluation, one bizarre conclusion finds drug court approach was 'more successful at reducing crime related to drug use and addiction but relatively less successful at reducing crime driven by other criminal impulses and motivation' (Rempel et al., 2003: 306), begging the question why these individuals were being sent to treatment centers in the first place.

7 Also see Cruikshank (1999: 67-89), who used the example of the War on Poverty and related reforms to show how their goals were to generate new citizen/subjects whose self-interests should ideally intersect with the government and the need for democratic reform, thus showing how new 'democratic subjects' are engendered through social service programs and community participation.

8 The defense bar has most to lose in this process and has the most reservations as the role of the defense lawyer changes from fighting for a client's innocence to maneuvering to reduce the mandates and requirements imposed by convincing the judge that the case does not merit the mandate, or the client does not need the treatment. The defense lawyers are in a conflictive role - many have advocated for more social services for their clients, but in this new model they are part of a team where ideals of guilt and innocence are exchanged for ideals of healing, helping and transformation (Malkin, 2003). They are also faced with the reality that most cases do not go to trial and are settled through pleas.

\section{References}

Abel, Richard (ed.) (1982) The Politics of Informal Justice. New York: Academic Press. Bazemore, Gordon (1998) 'Issues, Themes, and Questions for the New Neighborhood Sanctioning Models', in D. Karp (ed.) Community Justice: An Emerging Field. Lanham, MD: Rowman and Littlefield.

Berman, Greg (2000) 'What Is a Traditional Judge Anyway? Problem Solving in the State Courts', Judicature 84(2): 78-85.

Berman, Greg and John Feinblatt (2001) 'Problem Solving Courts: A Brief Primer', Law and Policy 23(2): 125-40.

Bratton, William and Rudolf Giuliani (1994) Police Strategy No. 5: Reclaiming the Public Spaces of New York. New York: City of New York.

Bureau of Justice Assistance (1998) Overcoming Obstacles to Community Courts: A Summary of Workshop Proceedings, Community Justice Series (prepared by the Center of Court Innovation). Washington, DC: US Department of Justice.

Bureau of Justice Assistance (2000) Community Courts: An Evolving Model, Community Justice Series \#2 (prepared by Eric Lee). Washington, DC: US Department of Justice.

Butts, Jeffrey (2001) 'Introduction to the Special Issue on Problem Solving Courts', Law and Policy 23(2): 121-4.

Chambliss, William and Marjorie Zatz (eds) (1993) Making Law: The State, the Law and Structural Contradictions. Bloomington: Indiana University Press.

Clear, Todd and David Karp (1999) The Community Justice Ideal. Preventing Crime and Achieving Justice. Boulder, CO: Westview Press.

Conley, John and William O'Barr (1990) Rules versus Relationships: The Ethnography of Legal Discourse. Chicago, IL: University of Chicago Press.

Cruikshank, Barbara (1999) The Will to Empower: Democratic Citizens and Other Subjects. Ithaca, NY: Cornell University Press. 
Davis, Wendy (2003) 'Specialty Problems for Specialty Courts', American Bar Association Journal 89: 32.

Department of Justice (1999) Looking at a Decade of Drug Courts (prepared by the Office of Justice Programs Programs). Washington, DC: Drug Court Clearinghouse Project and Technical Assistance Project at American University.

Erzen, Tanya (2001) 'Turnstyle Jumpers and Broken Windows Policing. Disorder in New York City', in A. McArdle and T. Erzen Zero Tolerance: Quality of Life and the New Police Brutality in New York City, pp. 19-49. New York: New York University Press.

Ewick, Patrick and Susan Silbey (1998) The Common Place of Law: Stories From Everyday Life. Chicago, IL: University of Chicago Press.

Fagan, Jeffrey and Victoria Malkin (2003) 'Theorizing Community Justice through Community Courts', Fordham Urban Law Journal 30(3): 897-954.

Feinblatt, John and Greg Berman (2001) 'Community Courts: A Brief Primer', United States Attorney's Bulletin 49: 33-40.

Feeley, Malcolm and Jonathan Simon (1992) 'The New Penology: Notes on the Emerging Strategy of Corrections and its Implications', Criminology 30(4): 444-69.

Flynn, Kevin (2000) 'Police Feel Scorn on Beat and Pressure from Above', New York Times 26 December: 1 (sect. 1).

Garland, David (2001) The Culture of Control: Crime and Social Order in Contemporary Society. Chicago, IL: University of Chicago Press.

Goode, Judith and Jeff Maskovosky (2001) 'Introduction', in J. Goode and J. Maskovosky The New Poverty Studies: The Ethnography of Power, Politics and Impoverished People in the United States, pp. 1-36. New York: New York University Press.

Greenhouse, Carol, Babara Yngvesson and David Engel (1994) Law and Community in Three American Towns. Ithaca, NY: Cornell University Press.

Gregory, Steven (1998) Black Corona: Race and the Politics of Place in an Urban Community. Princeton, NJ: Princeton University Press.

Hyatt, Susan Brin (1999) 'Poverty in a "Post-Welfare" Landscape: Tenant Management Policies, Self-Governance and the Democratization of Knowledge in Great Britain', in C. Shore and Wright (eds) Anthropology of Policy, pp. 217-31. London: Routledge.

Hyatt, Susan Brin (2001) 'From Citizen to Volunter: Neoliberal Governance and the Erasure of Poverty', in J. Goode and J. Maskovosky (eds) The New Poverty Studies: The Ethnography of Power, Politics and Impoverished People in the United States, pp. 210-35. New York: New York University Press.

Katznelson, Ira (1981) City Trenches: Urban Politics and the Patterning of Class in the United States. New York: Pantheon Books.

Kurki, Leena (2000) 'Restorative and Community Justice', Crime and Justice Research: A Review of Research 27: 235-303.

Lane, Eric (2003) 'Due Process and Problem Solving Courts', Fordham Urban Law Review 30(3): 955-1026.

Malkin, Victoria (2003) 'Community Courts and the Process of Accountability. Consensus and Conflict at the Red Hook Community Justice Center', American Criminal Law Review 40(4): 1573-93.

Merry, Sally (1982) 'Defining Success in the Neighborhood Justice Movement', in R. Tomasic and M. Feeley (eds) Neighborhood Justice - Assessment of an Emerging Idea, pp. 172-93. New York: Longman.

Merry, Sally (1990) Getting Justice, Getting Even: Legal Consciousness Among Working Class Americans. Chicago, IL: University of Chicago Press. 
Merry, Sally (1992) 'Anthropology, Law and Transnational Processes', Annual Review of Anthropology 21: 357-490.

Merry, Sally and Christine Harrington (1988) 'Ideological Production: The Making of Community Mediation', Law and Society Review 22(4): 709-36.

Messer, Ellen (1993) 'Anthropology and Human Rights', Annual Review of Anthropology 22: 221-93.

McConville, Mike and Chester Mirsky (1995) 'Guilty Plea Courts: A Social Disciplinary Model of Criminal Justice', Social Problems 42(2): 216-33.

Nader, Laura (1969) 'Introduction', in L. Nader (ed.) Law in Culture and Society. Chicago, IL: Aldine Publishing Company.

Nader, Laura (1997) 'Controlling Processes: Tracing the Dynamic Components of Power', Current Anthropology 38: 711-38.

Nieves, Evelyn (2000) 'California Gets Set to Shift on Sentencing Drug Users', New York Times 10 November: 18 (sect. A).

Nolan, James L., Jr (2001) Reinventing Justice: The American Drug Court Movement. Princeton, NJ: Princeton University Press.

O'Connor, Alice (1999) 'Swimming Against the Tide: A Brief History of Federal Policy in Poor Communities', in R. Ferguson and W. Dickens (eds) Urban Problems and Community Development, pp. 77-138. Washington, DC: Brookings Institution.

O'Malley, Pat (2000) 'Uncertain Subjects: Risks, Liberalism and Contract', Economy and Society 29(4): 460-84.

O'Malley, Pat and Darren Palmer (1996) 'Post-Keynesian Policing', Economy and Society 25(2): 137-55.

Ortner, Sherry (1991) 'Reading America: Preliminary Notes of Class and Culture', in R. Fox (ed.) Recapturing Anthropology, pp. 163-90. Santa Fe, NM: School of American Research Press.

Pavlich, George (2000) Critique and Radical Discourses on Crime. Aldershot: Ashgate Dartmouth.

Rashbaum, William (2000) 'Police Feel Scorn on Bet and Pressure from Above', New York Times 26 December: 1 (sect. A).

Rempel, Michael et al. (2003) The New York State Adult Drug Court Evaluation: Policies, Participants and Impacts. New York: Center for Court Innovation.

Rhodes, Lorna (2001) 'Towards an Anthropology of Prisons', Annual Review of Anthropology 30: 65-83.

Rose, Nikolas (1996) 'The Death of the Social: Refiguring the Territory of Government', Economy and Society 25(3): 327-56.

Rottman, David (1996) 'Community Courts: Prospects and Limits', National Institute of Justice Journal 231: 46-51.

Sampson, Robert (2001) 'Crime and Public Safety: Insights from Community-Level Perspectives on Social Capital', in S. Saegert, J.Thompson and M. Warren (eds) Social Capital and Poor Communities, pp. 89-114. New York: Russell Sage Foundation.

Shore, Chris and Susan Wright (1997) 'Policy: A New Field of Anthropology', in C. Shore and S. Wright (eds) Anthropology of Policy, pp. 3-34. London: Routledge.

Silbey, Silbey and Austin Sarat (1987), 'Critical Traditions in Law and Society Research', Law Eo Society Review 21(1): 165-74.

Simon, Jonathan (1997) 'Governing Through Crime', in L. Friedman and G. Fisher The Crime Conundrum, pp. 171-90. Boulder, CO: Westview Press.

Smandych, Russell (ed.) (1999) Readings on Governmentality and Crime Control. Aldershot: Ashgate Dartmouth. 
Stoutland, Sara (1999) 'Community Development Corporations; Mission Strategy and Accomplishments', in R. Ferguson and W. Dickens (eds) Urban Problems and Community Development, pp. 193-241. Washington, DC: Brookings Institution Press.

Valverde, Mariana (1998) Diseases of the Will: Alcohol and the Dilemmas of Freedom. Cambridge: Cambridge University Press.

Vincent, Robin (2002) 'Myths of Discipline: Beyond the Govermentalizing of Law in Lower Shepton', Anthropological Theory 2(3): 307-22.

Wilson, Richard (2000) 'Reconciliation and Revenge in Post-Apartheid South Africa', Current Anthropology 41: 75-98.

Winick, Bruce J. (2003) 'Therapeutic Jurisprudence and Problem Solving Courts', Fordham Urban Law Journal 30(3): 1055-90.

- Victoria Malkin received her PhD in Social Anthropology from University College London. The research for this article was completed while she was a staff associate at the Center for Violence Research and Prevention, Mailman School of Public Health, Columbia University. She currently works at the Wenner Gren Foundation for Anthropological Research. [email: vmalkin@wennergren.org] 